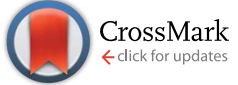

Cite this: RSC Adv., 2015, 5, 16702

Received 13th November 2014 Accepted 19th January 2015

DOI: $10.1039 / c 4 r a 14485 f$

www.rsc.org/advances

\section{Ultra-thick Li-ion battery electrodes using different cell size of metal foam current collectors}

\author{
Gui-Fu Yang, Kyung-Yup Song and Seung-Ki Joo*
}

In this study, ultra-thick Li-ion battery electrodes were prepared using 450, 800 and $1200 \mu \mathrm{m}$ cell size of metal foam current collectors for large scale energy storage. The thickness and the mass loading of the electrodes were in the range of 300-600 $\mu \mathrm{m}$ and $30-60 \mathrm{mg} \mathrm{cm}^{-2}$ respectively, which were much thicker and heavier comparing with the commercial electrodes. The cell using $1200 \mu \mathrm{m}$ cell size of metal foam exhibited the highest capacity $\left.(8.8 \mathrm{~mA} \mathrm{~h} \mathrm{~cm})^{-2}\right)$ at lower current density $\left(1 \mathrm{~mA} \mathrm{~cm}{ }^{-2}\right)$ owing to the highest mass loading of the active material. However, the deterioration of capacity and the voltage drop in plateau region were relatively much more with the increase of current density so that the capacity of cell using $800 \mu \mathrm{m}$ cell size of metal foam becomes the highest. AC impedance analysis showed that the charge transfer resistance difference between the cells using 450 and $800 \mu \mathrm{m}$ cell size of metal foams was only $1.5 \Omega \mathrm{cm}^{2}$ whereas it was $8 \Omega \mathrm{cm}^{2}$ between the cells using 450 and $1200 \mu \mathrm{m}$ cell size of metal foams. Furthermore, the slope of the straight line scanned at lower frequencies, which has relation with the diffusion limitation of Li was much lower for the cell using $1200 \mu \mathrm{m}$ cell size of metal foam. Considering both of the cell capacity and rate performance, the cell size of metal foam between 450 and $800 \mu \mathrm{m}$ is promising for commercial Li-ion batteries. Although the kinetic performance can be improved further by using the smaller cell size of metal foam, the cell capacity could be sacrificed due to the lower mass loading of the active material.

\section{A Introduction}

Li-ion batteries are more attractive for use in portable devices and clean electric vehicles because of their high energy density and high power density than other rechargeable batteries..$^{1-7}$ However, the major dilemma is that the thickness of active material for Li-ion battery is very thin. Our laboratory collected a lot of commercial Li-ion batteries and disconnected the batteries to measure the thickness of the electrodes. Generally, the thickness of the active material is around $50 \mu \mathrm{m}$ to $100 \mu \mathrm{m}$ for the portable devices ${ }^{8}$ whereas it is only $20 \mu \mathrm{m}$ to $60 \mu \mathrm{m}$ for hybrid electrical vehicles to sustain high power performance.

To overcome the issue, in previous study, a three dimensional metal foam was used as a new current collector instead of foil-type current collector. ${ }^{9}$ Considering the better kinetic performance of the cell using the metal foam, it is possible to increase the thickness of the electrode to increase the cell capacity and save the inactive materials such as current collector and separator. ${ }^{9}$ Because the mass loading of active material and the kinetic performance have relation with the cell size of metal foam current collector, it is worthwhile to optimize the cell by using different cell size of metal foams. In our study,

Research Institute of Advanced Materials (RIAM) and Department of Materials Science and Engineering, Seoul National University, Seoul 151-742, Korea.E-mail: skjoo@snu. ac. kr; Fax: +82-2-887-8791; Tel: +82-2-880-7442 the material of metal foam was NiCrAl alloy and the tolerance of material is sufficiently high enough as a current collector for Liion batteries. The cyclic voltammetric analysis showed that there was no anodic peak with a potential range of 2.0-5.0 V vs. $\mathrm{Li}^{+} / \mathrm{Li}$. Among the various active materials, carbon coated $\mathrm{LiFePO}_{4}$ is used as a positive electrode for Li-ion batteries, considering its low toxicity, high safety, potentially low cost, excellent life cycle, high structural stability, and large theoretical capacity (170 $\left.\mathrm{mA} \mathrm{h} \mathrm{g}^{-1}\right)$, and so on..$^{10-23}$

\section{B Experimental}

The commercial $\mathrm{Ni}$ foam substrate was manufactured by plating $\mathrm{Ni}$ on a three dimensional polyurethane and then the inner polyurethane was removed by heating. After the metallic $\mathrm{NiCrAl}$ alloy powder was adsorbed onto the resultant $\mathrm{Ni}$ foam, the substrate was reheated to obtain the NiCrAl alloy foam. The weight ratio of $\mathrm{Ni}, \mathrm{Cr}$ and $\mathrm{Al}$ was $77: 15: 8$. All the manufacturing processes were carried out at Alantum Corporation. Different cell size of NiCrAl alloy foams were used as positive electrode current collectors for the carbon-coated lithium iron phosphate $\left(\mathrm{LiFePO}_{4} / \mathrm{C}\right)$ battery. Each cell size was 450, 800 and $1200 \mu \mathrm{m}$, respectively and the thickness of each of them was around 700, 800 and $1200 \mu \mathrm{m}$, respectively, which were controlled via mechanical polishing. The slurry for the positive electrode was prepared by mixing $\mathrm{LiFePO}_{4} / \mathrm{C}$, 
conductive carbon black, and polyvinylidene fluoride (PVdF) at a weight ratio of $75: 15: 10$ with an $N$-methyl-2-pyrrolidone (NMP) solution. The prepared slurry was loaded into the metal foam uniformly, and the resultant electrode was dried and then pressed. Finally, the pressed electrode was annealed under a nitrogen atmosphere at $140{ }^{\circ} \mathrm{C}$ for half a day.

The cells were assembled in a dry glove box filled with pure argon gas, and each positive electrode was prepared with a lithium ribbon negative electrode, and these were placed into a glass tube $(\varphi \quad 28 \mathrm{~mm})$ containing $1 \mathrm{M} \mathrm{LiPF}_{6}$ electrolyte in ethylene carbonate (EC):diethyl carbonate (DEC) $(1: 1 \mathrm{v} / \mathrm{v})$. No distance was created between the positive electrode surface and the lithium ribbon surface using a separator. The size of metal foam was $1 \mathrm{~cm}$ by $2 \mathrm{~cm}$ and only half the area was loaded with the active material and the other area was used for connecting with the line of battery cycler system. The charge-discharge performance was evaluated using a constant current with a voltage range of $2.5-4.0 \mathrm{~V}$, and the cyclic voltammetric (CV) curves were measured at a scan speed of $0.1 \mathrm{mV} \mathrm{s}^{-1}$ with a potential range of 2.0-4.3 V. Both the charge-discharge test and the cyclic voltammetric analysis were evaluated using a WBCS3000 battery cycler system at room temperature. The AC impedance was analyzed using two electrode systems after the cell discharged completely at $0.1 \mathrm{C}$-rate. The frequency range was from $10^{5} \mathrm{~Hz}$ to $0.01 \mathrm{~Hz}$ with a signal of $5 \mathrm{mV}$ amplitude by using an electrochemical analyzer (Model CHI608A).

\section{Results and discussion}

The morphology of the NiCrAl alloy foams and the electrodes using different cell size of metal foams was observed using a scanning electron microscope (SEM, JEOL JSM-6360). As is shown in Fig. $1(\mathrm{~A}-\mathrm{C})$, a three dimensional framework structure can be observed and each cell consists of several pores. Obviously, the average pore size increased with the increase of the cell size (in the previous study, the cell size was considered as pore size ${ }^{9}$. The thicknesses of the 800 and $1200 \mu \mathrm{m}$ cell size of metal foams were reduced via mechanical polishing as the same as the cell size otherwise the electrodes would be too thick for commercial application. However, for the $450 \mu \mathrm{m}$ cell size of the metal foam, in order to obtain a thick electrode, the thickness was reduced to around $700 \mu \mathrm{m}$, which was one and a half times of the cell size. After manufacturing the electrodes using the above metal foams, the thickness of each of the electrodes was 330,430 and $540 \mu \mathrm{m}$, respectively, which were much thicker comparing with the commercial Li-ion battery electrodes ${ }^{8}$ and the amount of active material in each cell was $32.5,46.5$ and $56.3 \mathrm{mg} \mathrm{cm}{ }^{-2}$, respectively. As shown in the SEM images of the electrode surface and the cross-section [Fig. 1(a-c)], the average distance between the active material in the centre of the cell and the metal frame increased with the increase of cell size of the metal foam. It indicates that the capacity and the rate performance of the cell were related with the cell size of the metal foam current collector and it will be discussed further during the analysis of the electrochemical performance in the following section.

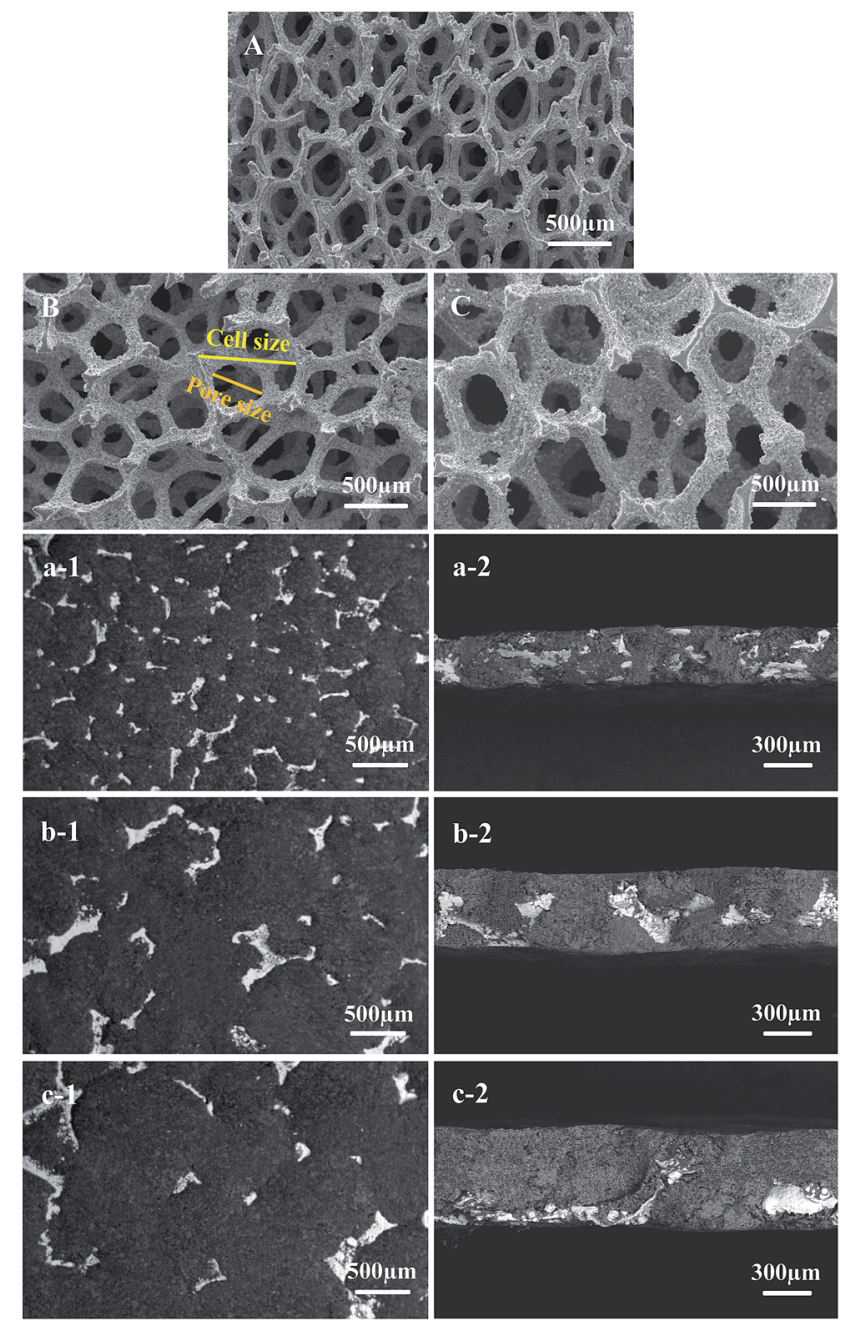

Fig. 1 SEM images of metal foams and the surface and cross-section of electrodes. $450 \mu \mathrm{m}$ cell size (A, a-1 and a-2), $800 \mu \mathrm{m}$ cell size (B, b-1 and $\mathrm{b}-2), 1200 \mu \mathrm{m}$ cell size (C, C-1 and $\mathrm{c}-2$ ).

As is shown in Fig. 2(a), the cell capacity exhibited higher at a lower current density in the case of larger cell size of metal foam because the mass loading of the active material is much higher for the larger cell size of metal foam; for example, each capacity of cell using $450,800,1200 \mu \mathrm{m}$ cell size of metal foams is 5.1, 7.2 and $8.8 \mathrm{~mA} \mathrm{~h} \mathrm{~cm}$, respectively at $1 \mathrm{~mA} \mathrm{~cm}{ }^{-2}$. It should be noted that there is almost no difference in specific capacity at lower current rate, which was close to theoretical capacity. However, the cell capacity decreased much more for the cell using lager cell size of metal foam especially for the $1200 \mu \mathrm{m}$ at higher current density. The capacity of cell using $1200 \mu \mathrm{m}$ cell size of metal foam was not the largest any more when the current density was more than $3 \mathrm{~mA} \mathrm{~cm} \mathrm{~cm}^{-2}$ and there was almost no big difference in the capacity comparing with the cell using $450 \mu \mathrm{m}$ cell size of metal foam when the current density was more than $5 \mathrm{~mA} \mathrm{~cm}^{-2}$. Additionally, the coulombic efficiency of the cell using $1200 \mu \mathrm{m}$ cell size of metal foam was much worse than in the case of the smaller cell size of metal foam in the range of 2-6 $\mathrm{mA} \mathrm{cm}^{-2}$. The current rate performance of the cells was also evaluated as is shown in Fig. 2(b). In lower current rate, 


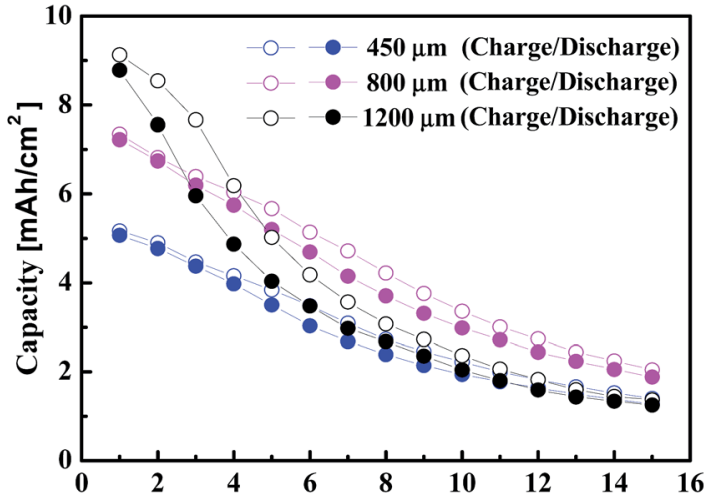

(a)

Current density $\left[\mathrm{mA} / \mathrm{cm}^{2}\right]$

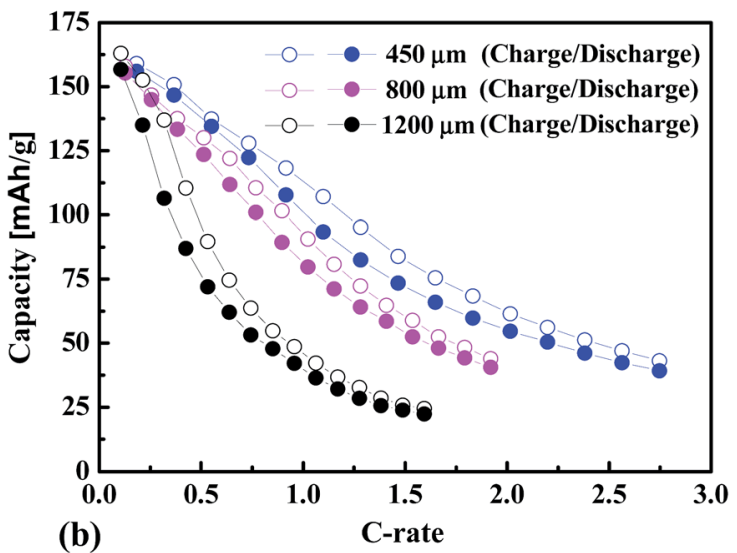

Fig. 2 Variation in the cell capacity and specific capacity with an increase in current density (a) and C-rate (b), for the cells using different cell size of metal foams.

there was almost no difference in specific capacity for the cells regardless of cell size of metal foams because there was no difference in diffusion limitation of Li-ion. However, in higher current rate, the diffusion limitation causes more for the thicker electrode. Additionally, the charge transfer ability decreased because the triple contact area per active material mass was much smaller and the average distance between the metal frame and the active material particles was much longer for the cell using the larger cell size of metal foam. According to the results, the cell using $1200 \mu \mathrm{m}$ cell size of metal foam showed relatively poor rate performance comparing with the cells using 450 and $800 \mu \mathrm{m}$ cell size of metal foams. For instance, at 1.0 Crate, the specific capacity was only $40 \mathrm{~mA} \mathrm{~h}^{-1}$ for the cell using $1200 \mu \mathrm{m}$ cell size of metal foam, whereas it was 100 and $80 \mathrm{~mA} \mathrm{~h}$ $\mathrm{g}^{-1}$, respectively for the cell using 450 and $800 \mu \mathrm{m}$ cell size of metal foams.

As shown in Fig. 3(a), there was no difference in power performance in plateau region for the cells using the different cell size of metal foam current collectors because the overpotential was almost the same in that region at lower current density $\left(2 \mathrm{~mA} \mathrm{~cm}{ }^{-2}\right)$. However, at higher current density, for example at $11 \mathrm{~mA} \mathrm{~cm}^{-2}$ as shown in Fig. 3(b), the over-potential of cell using $1200 \mu \mathrm{m}$ cell size of metal foam increased much faster compared with the cells using the smaller cell size of
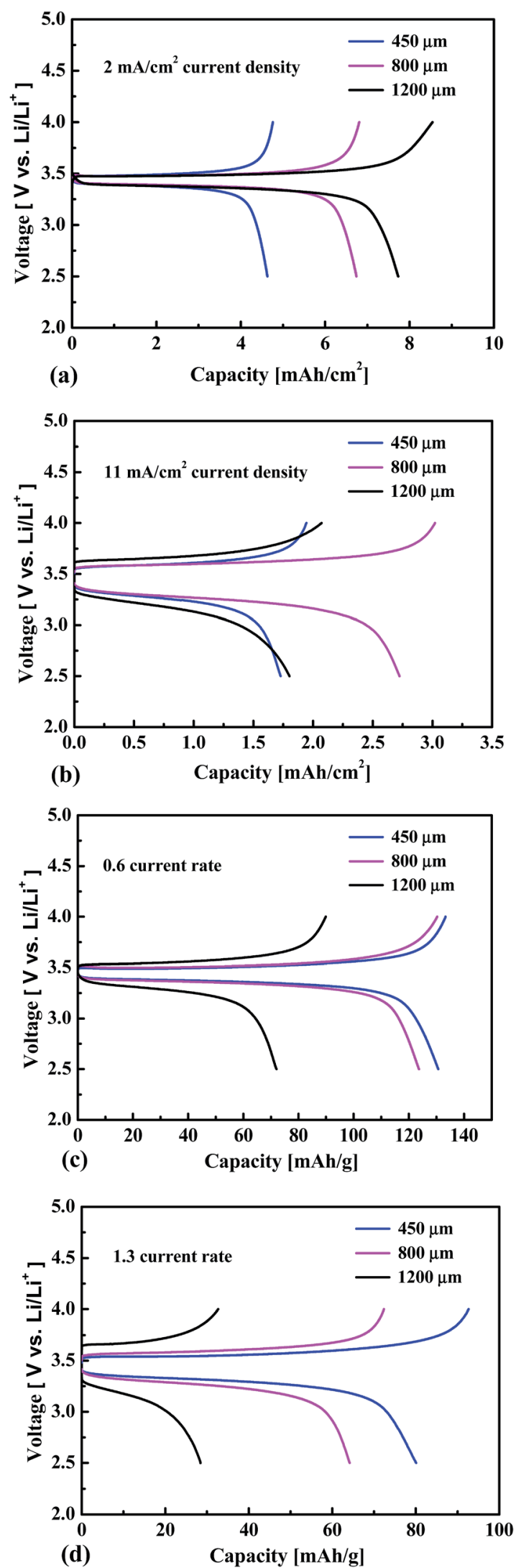

Fig. 3 Comparison of the charge-discharge curves at $2 \mathrm{~mA} \mathrm{~cm}^{-2}(\mathrm{a})$, $11 \mathrm{~mA} \mathrm{~cm}{ }^{-2}$ (b), $0.6 \mathrm{C}$-rate (c) and $1.3 \mathrm{C}$-rate (d) for the cells using different cell size of metal foams. 
metal foams because of the diffusion limitation of Li-ion and the higher charge transfer resistance. As shown in Fig. 4, there was no significant difference in bulk resistance for the cells. However, the charge transfer resistance difference between the cells using 450 and $800 \mu \mathrm{m}$ cell size of metal foams was $1.5 \Omega$ $\mathrm{cm}^{2}$ and it was $8 \Omega \mathrm{cm}^{2}$ between the cells using 450 and $1200 \mu \mathrm{m}$ cell size of metal foams. Additionally, the slope of straight line scanned at lower frequencies, which has relation with diffusion limitation was much lower for the $1200 \mu \mathrm{m}$ cell than in the case of the smaller cell size of metal foams. When the impedance was calculated using a unit of " $\Omega \mathrm{cm}^{2}$ ", both the redox area and electronic conductivity of electrode should be considered (the electrode density was controlled very carefully during the calendering process to avoid the effect of electrode density on the electronic conductivity. The electrode density was around $1.35 \mathrm{~g} \mathrm{~cm}^{-3}$ for the electrodes and the calculation method can be found in previous study ${ }^{9}$ ). For the thick electrode, the redox area was much larger due to the higher mass loading of active material that can result in lower impedance (the redox area of electrode equals to the total junction area between active material particles and electrolyte in the case of lower current rate and the effective redox area decreased in the case of higher current rate due to the diffusion limitation of Li-ion). However, the lower electronic conductivity can result in higher impedance due to the increase of cell size of metal foam. Thus, it is possible that there was no significant difference in impedance for the cells using 450 and $800 \mu \mathrm{m}$ cell size of metal foams. The equivalent circuit was obtained by fitting the impedance spectra as shown in the inset of Fig. 4. Yao et al. also reported the same result by using $\mathrm{Ni}-\mathrm{Cr}$ alloy foam current collector. ${ }^{24} R_{\mathrm{b}}, R_{\mathrm{CT}}, Z_{\mathrm{W}}$, $C_{\mathrm{dl}}$ represent the ohmic resistance, charge transfer resistance, the Warburg impedance, and the capacitance of double layer, respectively. Although the mass loading of the active material was the largest for the $1200 \mu \mathrm{m}$ cell size of metal foam, the deterioration of capacity and the voltage drop in the plateau region were relatively much more because of the higher charge transfer resistance and diffusion limitation of Li-ion. If the cell performance was evaluated in current rate, obviously, the rate performance was better for the cell using smaller cell size of metal foam as shown in Fig. 3(c) and (d).

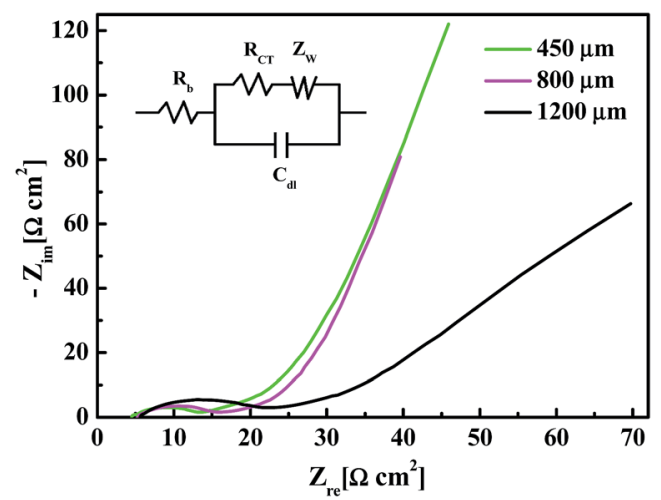

Fig. 4 Comparison of the AC impedance curves for the cells using different cell size of metal foams.
The electrochemical performance of cells was also evaluated by cyclic voltammetric analysis. As is shown in Fig. 5 , the redox peak of cell using smaller cell size of metal foam occurred earlier and the specific current of peak was higher; however, it should be noted that the specific current of peak was much smaller and the shape of peak was much broader for the cell using $1200 \mu \mathrm{m}$ cell size of metal foam. Due to the lower charge transfer ability, the Li concentration gradient was much lower at the electrode surface for the $1200 \mu \mathrm{m}$ cell, thus the specific diffusion flux of $\mathrm{Li}$ was also much lower according to the Fick's $1^{\text {st }}$ law. Additionally, the higher diffusion limitation of Li ion occurred because of the thickness of electrode. ${ }^{25,26}$ As shown in the curves, the difference in reduction current of peak between the 450 and $800 \mu \mathrm{m}$ cells was $18 \mathrm{~mA} \mathrm{~g}^{-1}$, whereas the difference was as much as $73 \mathrm{~mA} \mathrm{~g}^{-1}$ between the 450 and $1200 \mu \mathrm{m}$ cells. It indicates that much higher voltage difference was needed between the applied voltage and open circuit voltage (OCV) to insert or extract the same amount of $\mathrm{Li}$ for the large cell size of electrode.

The cycle-life performance of cells using the different cell size of metal foams was evaluated at $0.3 \mathrm{C}$ as is shown in Fig. 6 . After 50 cycles, the cell using smaller cell size of metal foam exhibited slightly better cycle stability; however, each cell capacity faded less than $10 \%$ of their capacity. The good cyclelife performance indicates that the tolerance of NiCrAl foam was sufficiently high enough. Additionally, the high tolerance of NiCral foam was confirmed by CV measurement and the result showed that there was no anodic peak with a potential range of 2.0-5.0 $\mathrm{V}$ at a scan speed of $0.1 \mathrm{mV} \mathrm{s}^{-1}$. The tolerance was much higher than in the case of the $\mathrm{Ni}-35 \mathrm{wt} \% \mathrm{Cr}$ alloy foam reported by Yao et al. ${ }^{24}$ and less content of $\mathrm{Cr}$ was needed by the addition of Al element in our study. Considering the cell capacity and rate performance, the cell size of metal foam between 450 and $800 \mu \mathrm{m}$ can be considered for commercial application especially for the large scale energy storage. However, the main issue in this study was that the metal foams manufactured for the emission control of vehicle engines were much heavier than the commercial foil type current collectors. To solve the issue, the thickness of $\mathrm{Ni}$ electroplated on the polyurethane and the weight ratio of $\mathrm{Ni}, \mathrm{Cr}$ and $\mathrm{Al}$ in metal foam should be controlled

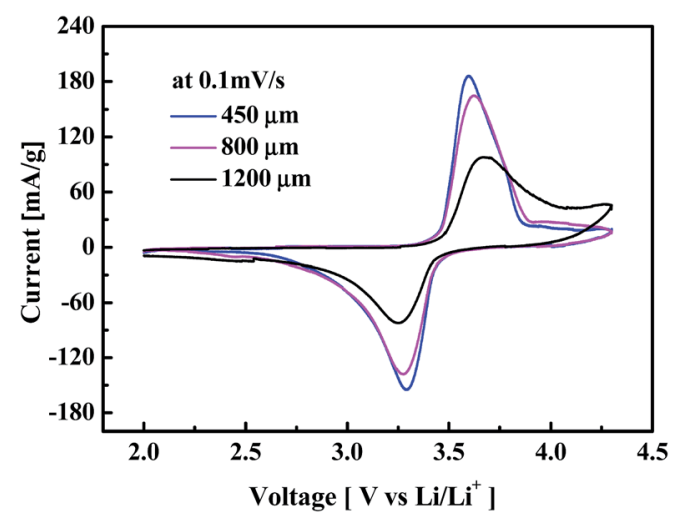

Fig. 5 Comparison of the cyclic voltammetric curves for the cells using different cell size of metal foams. 


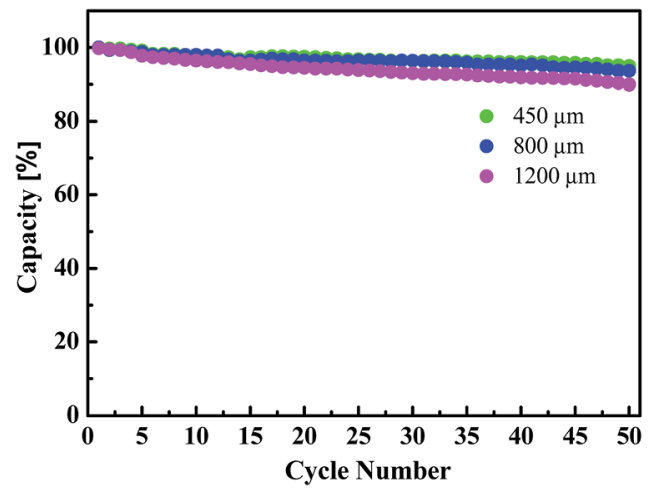

Fig. 6 Comparison of the cycle-life performance for the cells using different cell size of metal foams.

effectively to reduce the weight as much as possible for Li-ion batteries. Additionally, the specific surface area and the electric resistance of metal foam should also be considered. Currently, the electrode using a foil type usually was packed by rolling process, especially for the portable devices. However, when the electrode surface is large, some of the commercial Liion battery electrodes are packed via layered stacking. In our case, the thick electrode using metal foam should be packed by layered stacking to avoid the bending issue.

\section{Conclusions}

Ultra-thick Li-ion battery electrodes were prepared successfully in the range of 300-600 $\mu \mathrm{m}$ by using different cell size of metal foam current collectors. Although the electrode using $1200 \mu \mathrm{m}$ cell size of metal foam possesses the highest mass loading of active material, the cell capacity becomes lower than the cell using $800 \mu \mathrm{m}$ cell size of metal foam when the current density was higher than $3 \mathrm{~mA} \mathrm{~cm}^{-2}$. The AC impedance analysis showed that there was almost no difference in bulk resistance for the cells; however, higher charge transfer resistance and the lower slope of straight line scanned at lower frequencies were observed for the cell using $1200 \mu \mathrm{m}$ cell size of metal foam. Considering both of the cell capacity and rate performance, the cell size of metal foam between 450 and $800 \mu \mathrm{m}$ is promising for large scale energy storage.

\section{Acknowledgements}

This research was supported by Research Institute of Advanced Materials and Eui-San Research Center at Seoul National University. The authors acknowledge the support of metal foam from Alantum Corporation and lithium iron phosphate from Hanwha Chemical Corporation.

\section{Notes and references}

1 J. M. Tarascon and M. Armand, Nature, 2001, 414, 359-367.
2 K. Kang, Y. S. Meng, J. Breger, C. P. Grey and G. Ceder, Science, 2006, 311, 977-980.

3 B. L. Ellis, K. T. Lee and L. F. Nazar, Chem. Mater., 2010, 22, 691-714.

4 G. F. Yang, J. S. Song, H. Y. Kim and S. K. Joo, Jpn. J. Appl. Phys., 2013, 52, $10 \mathrm{MB13.}$

5 V. Etacheri, R. Marom, R. Elazari, G. Salitra and D. Aurbach, Energy Environ. Sci., 2011, 4, 3243-3262.

6 Y. Li, J. Song and J. Yang, Renewable Sustainable Energy Rev., 2014, 37, 627-633.

7 S. B. Chikkannanavar, D. M. Bernardi and L. Liu, J. Power Sources, 2014, 248, 91-100.

8 J. S. Wang, P. Liu, E. Sherman, M. Verbrugge and H. Tataria, J. Power Sources, 2011, 196, 8714-8718.

9 G. F. Yang, K. Y. Song and S. K. Joo, J. Mater. Chem. A, 2014, 2, 19648-19652.

10 H. Liu, Q. Cao, L. J. Fu, C. Li, Y. P. Wu and H. Q. Wu, Electrochem. Commun., 2006, 8, 1553-1557.

11 T. E. Ashton, J. V. Laveda, D. A. MacLaren, P. J. Baker, A. Porch, M. O. Jones and S. A. Corr, J. Mater. Chem. A, 2014, 2, 6238.

12 W.-B. Luo, S.-L. Chou, Y.-C. Zhai and H.-K. Liu, J. Mater. Chem. A, 2014, 2, 4927.

13 Y. Ding, Y. Jiang, F. Xu, J. Yin, H. Ren, Q. Zhuo, Z. Long and P. Zhang, Electrochem. Commun., 2010, 12, 10-13.

14 Z. Chen and J. R. Dahn, J. Electrochem. Soc., 2002, 149, A1184.

15 F. Gao, Z. Tang and J. Xue, Electrochim. Acta, 2007, 53, 19391944.

16 K. Kim, J. H. Jeong, I.-J. Kim and H.-S. Kim, J. Power Sources, 2007, 167, 524-528.

17 D. Jugović, M. Mitrić, M. Kuzmanović, N. Cvjetićanin, S. Marković, S. Škapin and D. Uskoković, Powder Technol., 2012, 219, 128-134.

18 Y. Zhang, L. Chen, J. Ou, J. Wang, B. Zheng, H. Yuan, Y. Guo and D. Xiao, J. Mater. Chem. A, 2013, 1, 7933.

19 Z.-X. Chi, W. Zhang, F.-Q. Cheng, J.-T. Chen, A.-M. Cao and L.-J. Wan, RSC Adv., 2014, 4, 7795.

20 Z. Bi, X. Zhang, W. He, D. Min and W. Zhang, RSC Adv., 2013, 3, 19744.

21 C. Jin, X. Zhang, W. He, Y. Wang, H. Li, Z. Wang and Z. Bi, RSC Adv., 2014, 4, 15332.

22 Y. Jiang, S. Liao, Z. Liu, G. Xiao, Q. Liu and H. Song, J. Mater. Chem. A, 2013, 1, 4546.

23 P. Yan, L. Lu, X.-m. Liu, Y. Cao, Z.-p. Zhang, H. Yang and X.-d. Shen, J. Mater. Chem. A, 2013, 1, 10429.

24 M. Yao, K. Okuno, T. Iwaki, M. Kato, S. Tanase, K. Emura and T. Sakai, J. Power Sources, 2007, 173, 545-549.

$25 \mathrm{H}$. Zheng, J. Li, X. Song, G. Liu and V. S. Battaglia, Electrochim. Acta, 2012, 71, 258-265.

26 S. Yu, S. Kim, T. Y. Kim, J. H. Nam and W. I. Cho, J. Appl. Electrochem., 2012, 43, 253-262. 